\title{
31. Oceanographical Observation of Matusima Bay, Miyagi Prefecture in the Winter of $1937^{*}$.
}

\author{
By Shinkichi Yoshimura and Syôzô NisiYama.
}

Institute of Geology and Palaeontology, Tohoku Imperial University, Sendai.

(Comm. by H. YABE, M.I.A., April 12, 1937.)

Matusima is an enclosed bay, $10 \times 5 \mathrm{~km}$ (area $38 \mathrm{~km}^{2}$ ) in extension, and faces the Pacific coast of northeastern Honsyû. It is richly indented with many small islets and separated from the Pacific Ocean by five main islands and connected with it by five channels. Two of these channels are narrow and shallow, while the other three are wider and deeper, sounding $10-13 \mathrm{~m}$. The inner bay is very shallow, sounding 1-5 $\mathrm{m}$ at low tide, except for the Siogama harbour which has been deepened artificially. The bottom sediment of the bay consists of thick green mud overgrown by sea-weeds. Many rafts for oyster culture and fishtraps are found at the northern half of the bay. The southern sea area immediately outside of the bay is $5-7 \mathrm{~m}$ deep, and the bottom consists of coarse sand and molluscan shells.

Oceanographical observations were made at 52 stations in the inner bay and a part of the outer sea during February 10-13th, 1937, with the assistance of Messrs. S. Nomura and S. Itô of the Saitô Hồ-on Kai Museum; of these stations 5 are on the shore and the remaining on the sea where the motor-boat "Singû" of the Doboku Syuttyôzyô of Sendai was used for observation.

At every station was observed the water temperature, salinity at surface, $2,5 \mathrm{~m}$ and at the bottom, and the transparency and water color. Bottom samples were collected for microscopic benthonic faunae by aid of Ekman-Birge's bottom sampler. Plankton were also taken at each station. The preliminary report of our survey follows.

During our observations, the weather was cloudy or rainy but rather warm and the sea was calm throughout.

Owing to the shallowness of the bay, the difference of water temperature between the surface and bottom was within $1^{\circ} \mathrm{C}$ at all stations and the surface temperature was always lower than the bottom one. The surface temperature for the outer sea was $4.8^{\circ}$ and at the western half of the bay $5.5^{\circ} \mathrm{C}$; towards the northern and eastern parts of the bay, the temperature gradually lowered and the minimum was $2.5^{\circ} \mathrm{C}$. The eastern bay head is connected with the outer sea by narrow straits which afford but poor exchange of water, thus their shore-margins were frozen during the winter of 1936 and probably an explanation for the lower temperature there might be found (Fig. 1).

Salinity at the surface ranged from $32 \%$ at the outer sea to $25 \%$ at the bay heads, and $29-30 \%$ at the eastern and middle parts. The absence of drainage from land at the eastern part of the bay resulted in the relatively higher salinity there, in spite of its

* Studies on the Lagoons and Enclosed Bays of Japan, Report No. 1. 


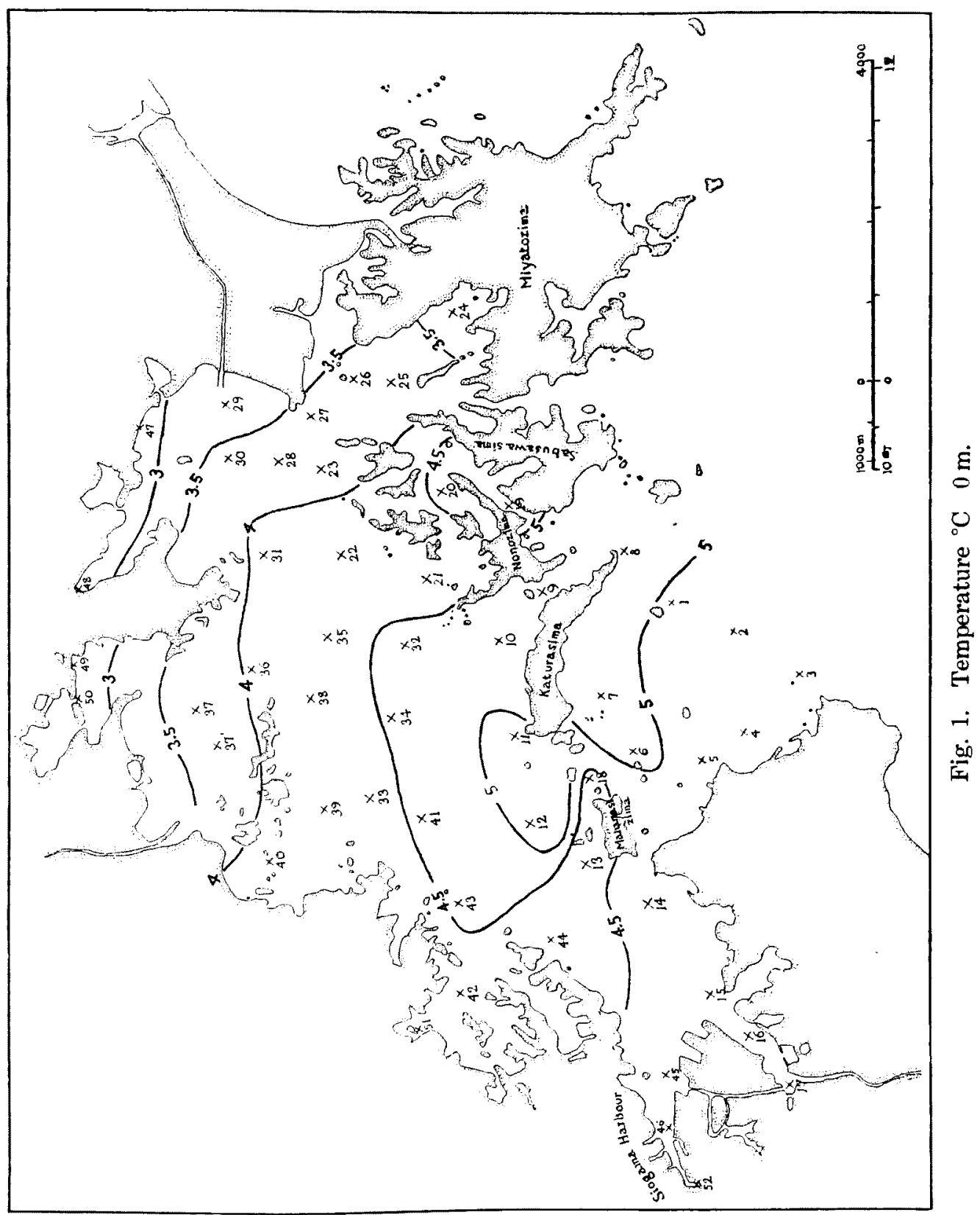

shallowness and poor water exchange with the outer sea. The salinity at $2 \mathrm{~m}$ level slightly exceeded that of the surface; 'this difference was greatest at the northern and western parts of the bay where drainage from the land diluted the sea water. The salinity at $2 \mathrm{~m}$ level at the middle part of the bay was 30.5-31.5\% \% . (Fig. 2).

Oxygen dissolved to nearly saturation at every station except those of Siogama harbour at the western corner where discharged water from factories polluted the water. $\mathrm{pH}$ was 8.1 at every station except the bay heads of Siogama harbour where the reaction tended to neutral owing to the contamination.

The transparency was greatest inside the bay, especially at the eastern corner where the maximum was $3.7 \mathrm{~m}$; at the outer sea it was only $2 \mathrm{~m}$. The rough outer sea may reduce the transparency by dis- 


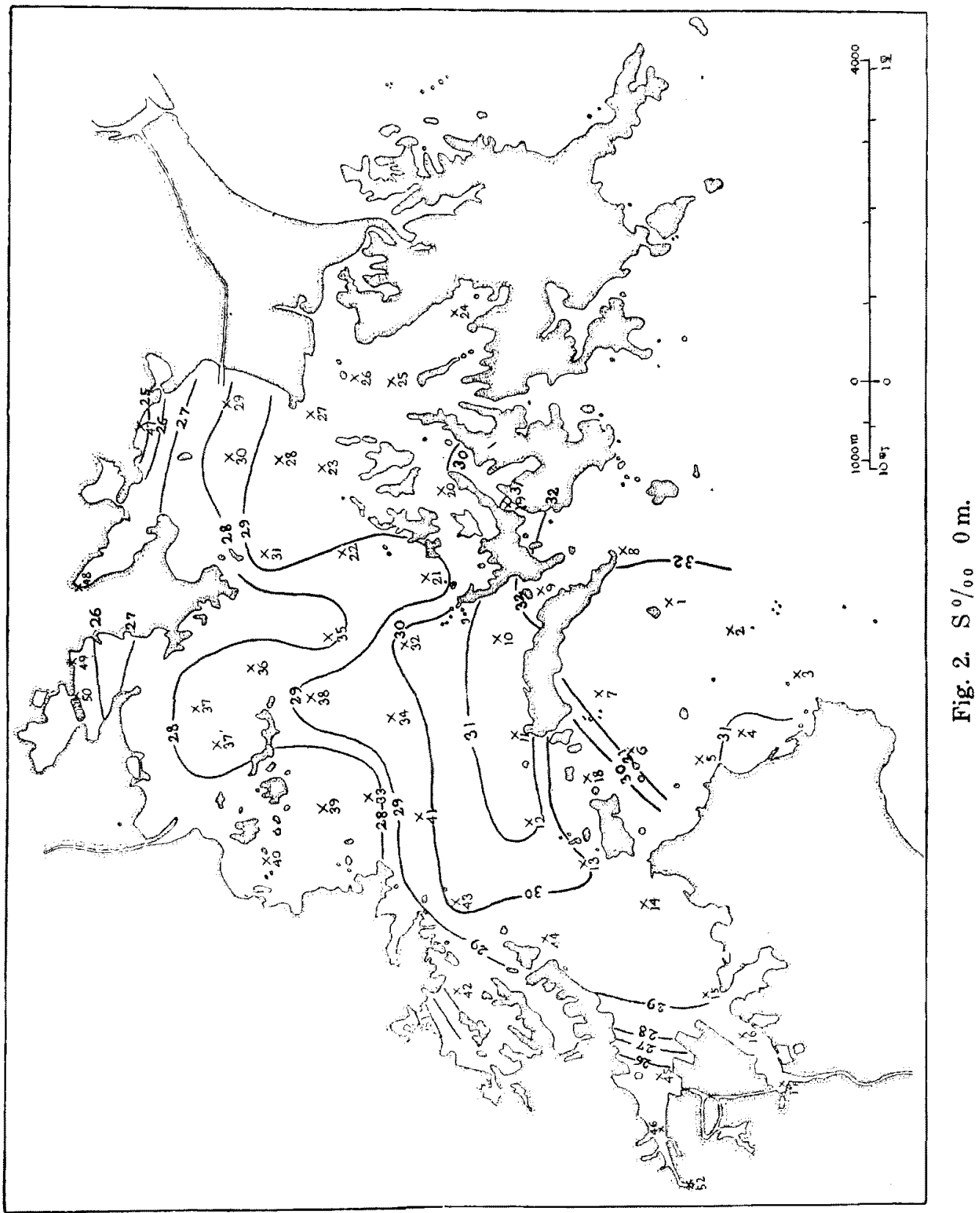

turbing the bottom deposits, while the sheltered enclosed bay of calm water might answer for the greater transparency.

The sea-water of Matusima bay consists of four different masses, they are;

1. Warm and saline mass at the south to middle of the bay

2. Cold and brackish mass at the northern and western corners of the bay

3. Cold and comparatively saline mass at the eastern corner of the bay

4. Polluted mass at the western corner of the bay.

The water exchange between the outer sea and inner bay is greatest between Katurasima and Nonosima (Isihama Strait), where the maximum velocity of tidal currents is 2 knots; next is the channel between Katurasima and Mahanasizima, of 1 knot. Other channels being narrow and shallow, have little bearing on distribution of hydrographical conditions of the bay. 
TABLE

Hydrographical Observation of Matusima Bay

\begin{tabular}{|c|c|c|c|c|c|c|c|c|}
\hline Station & Date & $\begin{array}{l}\text { Depth } \\
\text { in } \mathrm{m}\end{array}$ & $\underset{{ }^{\circ} \mathrm{C}}{\text { Temp. }}$ & $\underset{\mathrm{g} / 1}{\mathrm{~S}}$ & $\begin{array}{c}0_{2} \\
\text { c.c. } / 1\end{array}$ & $\begin{array}{l}0_{2} \\
\%\end{array}$ & $\mathrm{pH}$ & $\begin{array}{l}\text { Trans- } \\
\text { parency }\end{array}$ \\
\hline 3 & Feb. 10 & $\begin{array}{l}0 \\
2 \\
6\end{array}$ & $\begin{array}{l}4.8 \\
5.4 \\
5.5\end{array}$ & $\begin{array}{l}31.13 \\
31.69 \\
32.20\end{array}$ & $\begin{array}{l}7.30 \\
7.08 \\
6.75\end{array}$ & $\begin{array}{l}98 \\
98 \\
94\end{array}$ & $\begin{array}{l}8.0 \\
8.1 \\
8.1\end{array}$ & 2.2 \\
\hline 9 & Feb. 10 & $\begin{array}{r}0 \\
5 \\
13\end{array}$ & $\begin{array}{l}5.6 \\
5.6 \\
5.8\end{array}$ & $\begin{array}{l}32.16 \\
32.16 \\
32.36\end{array}$ & $\begin{array}{l}7.11 \\
7.13 \\
6.92\end{array}$ & $\begin{array}{l}99 \\
99 \\
97\end{array}$ & $\begin{array}{l}8.1 \\
8.05 \\
8.05\end{array}$ & 2.1 \\
\hline 22 & Feb. 11 & $\begin{array}{l}0 \\
2 \\
3.5\end{array}$ & $\begin{array}{l}4.4 \\
4.5 \\
5.0\end{array}$ & $\begin{array}{l}28.91 \\
29.24 \\
30.73\end{array}$ & $\begin{array}{l}7.77 \\
7.74 \\
7.32\end{array}$ & $\begin{array}{r}103 \\
104 \\
99\end{array}$ & $\begin{array}{l}8.1 \\
8.15 \\
3.15\end{array}$ & 2.6 \\
\hline 37 & Feb. 12 & $\begin{array}{l}0 \\
1\end{array}$ & $\begin{array}{l}3.7 \\
3.7\end{array}$ & $\begin{array}{l}28.48 \\
28.48\end{array}$ & $\begin{array}{l}7.64 \\
7.55\end{array}$ & $\begin{array}{r}100 \\
99\end{array}$ & $\begin{array}{l}8.1 \\
8.0\end{array}$ & - \\
\hline 45 & Feb. 12 & $\begin{array}{l}0 \\
2 \\
8\end{array}$ & $\begin{array}{l}4.6 \\
4.8 \\
5.1\end{array}$ & $\begin{array}{l}25.64 \\
30.28 \\
30.93\end{array}$ & $\begin{array}{l}6.58 \\
6.92 \\
6.00\end{array}$ & $\begin{array}{l}85 \\
93 \\
82\end{array}$ & $\begin{array}{l}7.8 \\
8.05 \\
8.0\end{array}$ & 2.0 \\
\hline
\end{tabular}

St. 3, outer sea, near Mizusima. St. 9, in deep Isihama Strait between Nonosima and Katurasima. St. 22, center of bay. St. 37, in narrow channel at northwestern corner of bay. St. 45, in Siogama harbour, at western corner of bay where sea water is polluted.

Finally the writers wish to thank the Sendai Doboku Syuttyôzyô for the free use of their motor-boat "Singu," and the Imperial Academy for the financial support enabling the prosecution of the present study. Acknowledgements are also due to Prof. H. Yabe of the Institute of Geology and Palaeontology, Tôhoku Imperial University and Messrs. S. Nomura and S. Itô of the Saitô Hô-on Kai Museum, both in Sendai, for their sincere helps in many ways. 